RESEARCH ARTICLE

\title{
Investigating digital native female learners' attitudes towards paperless language learning
}

\author{
Tsoghik Grigoryan* \\ General Studies Program, Higher Colleges of Technology, Al Ain, United Arab Emirates
}

(Received: 18 October 2016; final version received: 10 January 2018)

\begin{abstract}
This study is an investigation of paperless language learning in the context of the United Arab Emirates. The purpose of this study was to examine Emirati level 1 English language learners' attitudes towards the iPad use as a means of language learning. It was done through a cross-sectional survey questionnaire, wholly composed of fixed-choice questions, and through weekly reflective journals that were written by the teachers teaching the groups. The survey collected data through a questionnaire from 80 students who had been exposed to paperless language learning for a duration of 80 teaching periods. The data collected showed positive student attitudes towards iPad implementation as a language learning tool in terms of learner satisfaction, motivation, perceived tool usefulness and learning effectiveness. Reflective journal analysis showed that the digital world presents the students with a direct link between the effort taken and the reward received, whereas the feedback or the reward given by the teachers in the traditional classroom was either too nebulous or too slow to motivate students to keep the pace of progressive learning.
\end{abstract}

Keywords: attitudes; English as a foreign language; iPad; language learning; mobile classroom; paperless

\section{Introduction}

Prensky (2012) has identified today's generational change that leads to a really big discontinuity, which one can call 'singularity': an event that changes things so fundamentally that there is no way back. He has used the term 'digital natives' and argued that the new generation is different from the previous ones because of the technological changes. Prensky's (2001) ideas about digital natives and digital immigrants were published more than 10 years ago, according to which a new generation of digital natives are presently entering the schools and other educational institutions. The urge for educators to accept the needs of this generation differently has become even more crucial. A fundamental problem raised by Prensky (2001) about today's educational system in the eyes of the new generation regards the absolute boredom in schools, which he explains with the promptly growing divide between the information and knowledge learners can get out of school and the narrow confines of their lives within it.

The traditional teaching methods, where teachers talk through textbooks and students listen, are regarded as an old practice not providing students with the skills they need for the modern world (Jukes, McCain, and Lee 2010). While teachers continue to teach many traditional skills, there will be a shift in emphasis of importance

*Corresponding author. Email: tgrigoryan@hct.ac.ae 


\section{T. Grigoryan}

of those skills (Jukes, McCain, and Lee 2010, p.63). There was a time when it was important to learn to write nicely and develop good handwriting. Despite the cognitive benefits of practicing good handwriting, its emphasis as an important skill has changed significantly. Learning has moved to a digital realm and writing is realised using digital software tools. This is only one example out of many possible ones that restates the importance of re-evaluating teaching and learning ways in light of the realities of the new digital world. Teachers no longer have to be in the centre of attention, but to become facilitators who can guide the learners to the answers they search for. Since there are no fixed right or wrong ways of integrating technology into the classroom, the solution is to come up with the most effective learning environment for learners.

This is obvious that the description and understanding of the learning has changed significantly over time and is still in its transformational modern stage, which necessitates exploration and investigation of the pros and cons of innovative changes in the field of English as a foreign language paperless classroom. 'This paperless system clears the way for communication beyond the space and time limitations inherent in any traditional course' (Dan 2002, p. 162). The move to paperless classroom is met mostly with fear and resistance to change by educators. On the contrary, it is mostly welcomed by today's learners.

Changes and challenges are not easy, but they are inescapable and need time to research the advantages and disadvantages they could bring to today's educational system. An example of this change was a tertiary level college in the United Arab Emirates (UAE) that went paperless and implemented iPads for its Foundations Programme, eliminating paper and pen teaching-learning methods from the classroom. The innovation brought up enormous challenges in the technical and methodological fields, as well as in language learning ways, skills and practices. Therefore, an investigation was needed to shed light on students' attitudes towards various aspects of that innovative change.

This study aimed at exploring the results of using mobile technology educationally by looking into learner attitudes towards using iPads in language learning. The research questions guiding this study were the following:

1. What are beginner level Emirati students' attitudes towards iPad implementation as a language learning tool in terms of learner satisfaction, motivation, perceived tool usefulness and learning effectiveness?

2. What are the emerging themes of the teachers' reflective journals in the evaluation of their lessons and diagnosis of problems?

The first research question was answered through a cross-sectional survey questionnaire, wholly composed of fixed-choice questions. The survey collected data through a questionnaire from four groups of 20 students who had been studying English paperless for 80 teaching-learning periods. The data analysis showed positive student attitudes towards iPad implementation as a language learning tool in terms of learner satisfaction, motivation, perceived tool usefulness and learning effectiveness.

The second research question was answered through the weekly reflective journals written by four teachers throughout the two phases of the experiment. The analysis of the 24 reflective journals showed that iPad-based learning carries more benefits than textbook-based learning in terms of motivation and learning effectiveness. Language achievement is more enjoyable when iPads are used as a means of learning. 


\section{Literature review}

Theories and approaches related to innovation adoption include, but are not limited to, diffusion of innovation theory (Rogers 2003), theory of reasoned action - TRA (Fishbein and Ajzen 2010), enhanced technology acceptance model - TAM (Venkatesh and Davis 2000), unified theory of acceptance and use of technology - UTAUT (Venkatesh and Davis 2000), social cognitive theory - SCT (Bandura 1999) and activity theory - AT (Engestrom 1999). Many other approaches have also emerged and have been developed from the above-mentioned models and theories to conduct research into technology use. In turn, they have been practiced in various spheres of life as well as in education.

Though information and communication technology (ICT) adoption is a well-researched area of study in information technology (IT) research, its application to education is still under investigation (Churchill and Wang 2014; Lai, Sham, and Tian 2014; Meder and Wegner 2015). Some educational institutions today insist on integrating mobile devices without determining their benefits and possible negative effects on students' education. Funding, innovative ways of management, ecological problems, modern pedagogies and other factors are all mentioned as hurdles for ICT adoption, yet the area lacks research and consensus (Meder and Wegner 2015).

Table 1 depicts six innovation adoption theories and discusses them accordingly. One of the approaches to the adoption of innovation that educational technologists will benefit greater understanding and awareness from is the diffusion of innovation theory. Diffusion of innovation theory explains how an idea or a product gains an impetus over time and diffuses through a specific population (Boczkowski 2010). It aims to study people's technology adoption in terms of time, innovation, communication methods and the social system. This means that people adopt an innovative product or a new idea and perceive it as new or innovative. Ghezzi, Rangone, and Balocco (2013) claim that diffusion theory should be revisited to identify external determinants that enable or hinder evaluation of the new technology prior to the technological activation phase in education. The model they propose addresses regulation, environment, strategy and technology (REST), which are the four determinants stimulating technology activation.

Another theory that postulates that the behavioural target is shaped by the individual's attitudes and subjective norms is the TRA. It was developed to describe the connection of individuals' behaviours and attitudes within their actions.

Table 1. Summary of innovation adoption theories.

\begin{tabular}{|c|c|c|c|c|c|}
\hline $\begin{array}{l}\text { Diffusion of } \\
\text { Innovation } \\
\text { Theory }\end{array}$ & $\begin{array}{l}\text { Theory of } \\
\text { Reasoned } \\
\text { Action }\end{array}$ & $\begin{array}{l}\text { Enhanced } \\
\text { Technology } \\
\text { Acceptance } \\
\text { Model }\end{array}$ & $\begin{array}{l}\text { Unified Theory } \\
\text { of Acceptance } \\
\text { and Use of } \\
\text { Technology }\end{array}$ & $\begin{array}{l}\text { Social } \\
\text { Cognitive } \\
\text { Theory }\end{array}$ & Activity Theory \\
\hline $\begin{array}{l}\text { Flexible } \\
\text { attitudes }\end{array}$ & $\begin{array}{l}\text { - Beliefs } \\
\text { - Attitudes }\end{array}$ & $\begin{array}{l}\text { - Perceived ease } \\
\text { of use } \\
\text { - Perceived } \\
\text { usefulness }\end{array}$ & $\begin{array}{l}\text { - Performance } \\
\text { expectancy } \\
\text { - Effort } \\
\text { expectancy }\end{array}$ & Sel & $\begin{array}{l}\text { Perceived ease } \\
\text { of use }\end{array}$ \\
\hline $\begin{array}{l}\text { - Comparability } \\
\text { - Observability }\end{array}$ & $\begin{array}{l}\text { Subjective } \\
\text { Norm }\end{array}$ & $\begin{array}{l}\text { - Subjective } \\
\text { - Result } \\
\text { demonstrability }\end{array}$ & $\begin{array}{l}\text { Social influence } \\
\text { Facilitating } \\
\text { Conditions }\end{array}$ & $\begin{array}{l}\text { Outcome } \\
\text { expectations }\end{array}$ & $\begin{array}{l}\text { Result } \\
\text { demonstrability }\end{array}$ \\
\hline
\end{tabular}




\section{T. Grigoryan}

The aim of the TRA is to investigate the relationship between attitude and behaviour based on two major concepts: principles of compatibility and behavioural intention. With this characteristic, the TRA is a predictive model and, therefore, is used in a variety of fields, such as banking, public, education, and industries to predict individuals' actions based on certain criteria. (Mishra, Akman, and Mishra 2014, p. 30)

The attitude and subjective norm are the central factors of individuals' objectives of implementing ICTs and were found to have a big impact on adopting ICT (Doane, Pearson, and Kelley 2014; Mishra, Akman, and Mishra 2014). Several studies found that subjective norm affects an individual's behavioural intention (Cooke and French 2008; Doane, Pearson, and Kelley 2014), satisfaction, information sharing (Tsai, Chen, and Chien 2012) and perceived usefulness (Venkatesh and Davis 2000).

The enhanced TAM suggests that perceived ease of use and perceived usefulness are direct channels of technology acceptance behaviours. According to Gong, $\mathrm{Xu}$, and $\mathrm{Yu}$ (2004), 'Perceived usefulness is defined as the prospective user's subjective probability that using a specific application system would increase his or her job performance within an organizational context' (p. 366). Perceived ease of use, on the other hand, 'refers to the degree to which the prospective user expects the target system to be free of effort' (p. 366). Several studies have used enhanced TAM as their theoretical background for explaining technology use and adoption (Gong, $\mathrm{Xu}$, and $\mathrm{Yu}$ 2004; Teo 2009) and found that perceived usefulness influences attitudes and satisfaction towards technology use (Limayem, Hirt, and Cheung 2007; Venkatesh and Davis 2000).

The UTAUT looks at how two factors - intention and behaviour - progress over time and are moderated by gender, age and experience (Venkatesh and Davis 2000). The determinants of intention are supposed to be the performance expectancy, effort expectancy and social influence, whereas the determinants of behaviour are supposed to be the intention and facilitating conditions (Venkatesh and Davis 2000).

SCT describes how the individual obtains and sustains a specific behaviour based on learning from others (Bandura 1999). This theory suggests that the acquisition of knowledge is related to observing others within the context of social interactions. It also explains that a specific behaviour can be influenced by final expectations and self-efficacy, while final expectations and self-efficacy can be affected by prior behaviour. Several studies have used SCT and found significant relationships with other concepts in ICT adoption and use, such as that self-efficacy can positively influence perceived ease of use and perceived usefulness (Bandura 2002; Chiu, Hsu, and Wang 2006; Swearer et al. 2014).

AT, as propounded in Soviet psychology, is the umbrella term for several eclectic social sciences theories. It is not a predictive theory, but more of a descriptive framework, which studies the whole activity system beyond one user. Therefore, AT was chosen as the framework of this study. AT is a cross-disciplinary framework for studying how humans purposefully transform natural and social reality, including themselves, as an ongoing culturally and historically situated, materially and socially mediated process' (Roth, Radford, and Lacroix 2012, p. 1). Entrenched in the dialectal psychology, it transcends traditional dichotomies of macro and micro, thought and action, intervention and observation, qualitative and quantitative by integrating three perspectives: objective, ecological and sociocultural perspectives (Engestrom 1999). Another reason why AT was used in this study was because in this theory the subject implements a tool to perform cognitive functions and cannot directly act on the object. The unit of analysis here is the concept of object-oriented, collective and culturally mediated human activity system. When iPad is used in language learning, it is not seen as the object of learning 
the language but as a device to realise the language acquisition process. Thus, based on the technological outlook of AT, individual functioning is considered to be distributed across and situated within the transaction of the contexts of the subject, available tools and community with the division of labour (Uden 2007 in Liaw and Huang 2014).

\section{Methodology}

\section{Site and subject selection}

The site of the study was the largest governmental higher learning institution in the UAE that had 17 campuses across the country. The institution provided post-secondary education to 17-25-year-old Emirati nationals. Campuses were segregated for male and female students but the multinational staff of both sexes taught at either campuses. The institution started the iPad project in 2012 at the Foundation Studies programme and moved from traditional language learning and teaching to paperless and mobile methods, which meant teaching and learning was realised solely through iPad applications, online resources and electronic texts. The Foundation Studies programme supported students needing English language assistance in meeting the admission criteria of the bachelor's degree programme prior to entering their chosen programme major. The programme offered four levels of English proficiency: beginner, pre-intermediate, intermediate and advanced. This experimental phase concentrated on the Foundation Studies programme and on the level of English proficiency called beginner level or level 1. This was the first of four English courses at the Foundations level. Students were expected to have Common European Framework of Reference (CEFR A1) competence at the beginning of the course with a target exit of A2. The beginner level and the Foundations language programme were chosen for the experiment because this was the programme and the level that all students needed to complete first as they entered the institution and this was when they tried iPads for language learning purposes for the first time.

Research participants were 17-25-year-old Emirati women who, after high school, were placed in higher institutions according to their Common Educational Proficiency Assessment (CEPA) test results. CEPA is a set of locally developed standardised tests used for admissions and placement by three federal institutions of higher education in the UAE. Students entered the institution at the CEFR A1 level, having a CEPA score of 150 and were expected to exit midway through CEFR A2 level with a score of CEPA 156. Out of 250 newly admitted students, 80 were randomly chosen for the experiment. Then, the 80 students were randomly placed in four different groups with 20 students each: two iPad groups and two textbook groups. The researcher and three other level 1 teachers were assigned to teach those groups, each teaching one group. The teachers were employed by the institution and were equally experienced and qualified to work with level 1 students.

\section{Methods and instruments}

The groups used the following textbooks for the course as mentioned in the Common Course Outline: Q: Skills for Success INTRO: Reading and Writing and Q: Skills for Success INTRO: Listening and Speaking. All four groups followed the work plan and covered the same material, although, with different methods of instruction.

As illustrated in Table 2, the iPad groups followed the conditions set by the institution and fully used iPads for their language learning, with no presence of traditional learning methods, such as paperback texts, stationary or pen-written notes. Instead, 


\section{T. Grigoryan}

they used annotation apps to complete the exercises, presentation apps to create presentations, interactive texts to complete reading and writing tasks and individual audios to complete the listening exercises. On the contrary, the textbook groups did not use iPads for anything and followed the traditional methods of using pen and paper for writing and paperback texts for reading. All groups covered the same material and followed the same programme with the different ways of teaching: with paper and paperless. The experiment lasted for 80 teaching periods, which was followed by the questionnaire administration. Each teaching period lasted for $50 \mathrm{~min}$. Students had four periods of English every day, from Sunday to Thursday. They did not take any other subjects except English throughout level 1. During both phases of the experiment, all four teachers kept weekly journals and reflected about the teaching and learning process.

After the first phase of the experiment, the two textbook groups that were not exposed to iPads became iPad groups in phase 2 and commenced their studies by using iPads for another 80 teaching periods. In this second phase, the groups used annotation apps to complete the e-book exercises, presentation apps to create multimedia presentations, interactive texts to complete reading and writing tasks and individual

Table 2. The treatment plan.

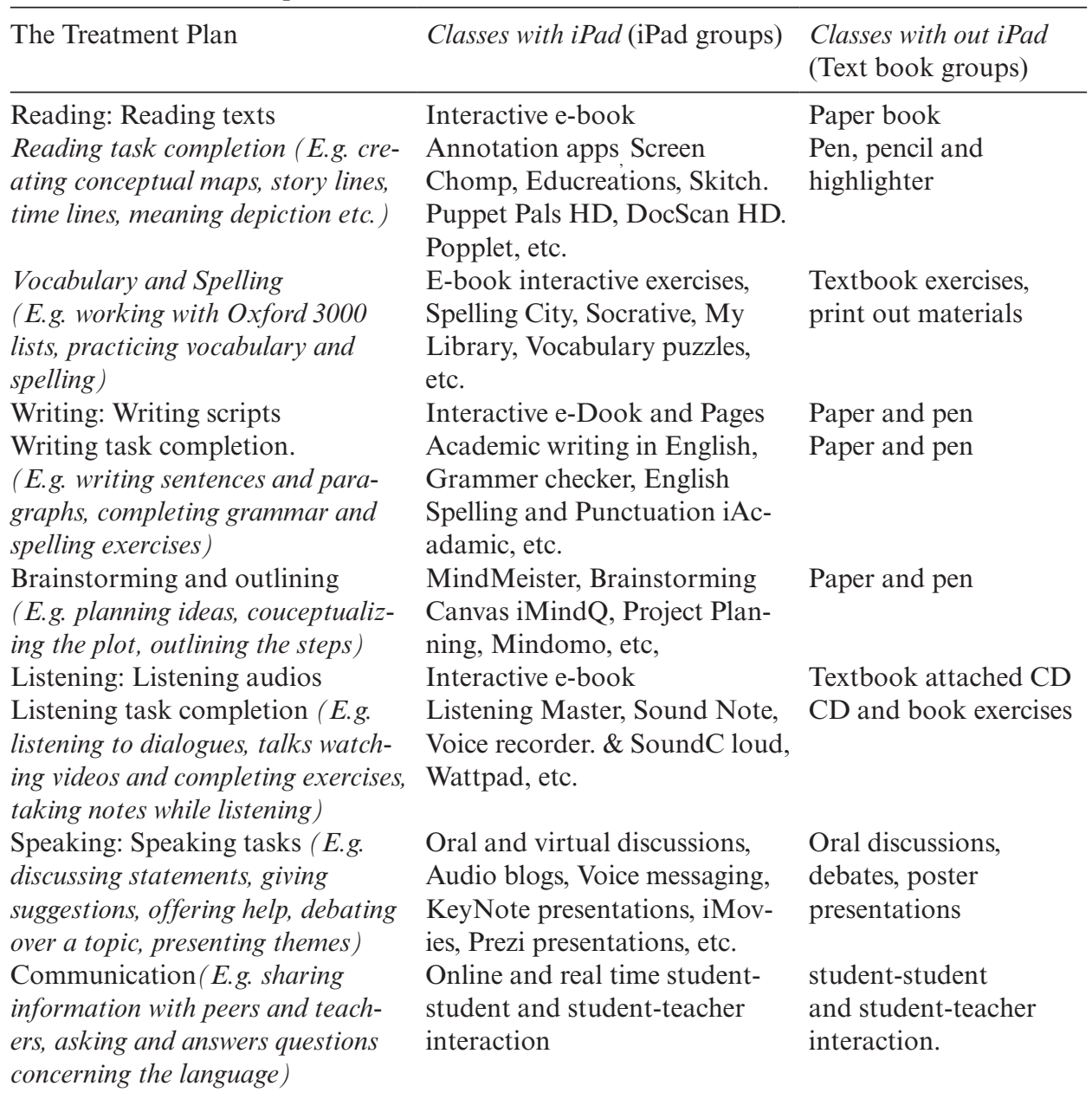


audios to complete the listening exercises. Another two units were covered from each textbook within 80 periods of English language class. Like after phase 1, the questionnaire was administered after phase 2 as well.

\section{Survey research}

This study presented the following 15 research hypotheses (see Table 3).

The cross-sectional self-completion fixed-design survey questionnaire was administered in two phases. The survey collected data through a questionnaire from predetermined population, that is to say, students from four groups under experiment: from two iPad groups in the first phase and two iPad groups in the second phase. Though survey method lacks control over variables and threats to validity, it yields empirical results. This approach was important for this study to answer its 15 hypotheses, describe the trends in the data and measure current attitudes and practices of the target population.

Table 3. Research hypothesis.

This research reports an Activity Theory based investigation into the use of iPads for language learning in terms of learner motivation, perceived satisfaction, perceived tool usefulness and learning effectiveness. This research tries to understand learners' attitudes toward iPads as language learning tools.

H1: Perceived self-efficacy has positive predictive value for perceived satisfaction toward iPads as language beaming tools.

H2: Perceived self-efficacy has positive predictive value for perceived usefulness toward iPads as language learning tools.

H3: Perceived self-regulation has positive predictive value for perceived satisfaction toward iPads as language learning tools.

H4: Perceived self-regulation has positive predictive value for perceived usefulness toward iPads as language learning tools.

H5: Interactive learning environment have positive predictive value for perceived satisfaction toward iPads as language learning tools.

H6: Interactive learning environments have positive predictive value for perceived usefulness toward iPads as language learning tools.

H7: Perceived ease of use has positive predictive value for perceived satisfaction toward iPads as language learning tools.

H8: Perceived ease of use has positive predictive value for perceived usefulness toward iPads as language learning tools.

H9: iPad based tasks have positive predictive value for perceived satisfaction toward iPads as language learning tools.

H10: iPad based tasks have positive predictive value for perceived usefulness toward iPads as language learning tools.

H11 : Perceived satisfaction has positive predictive value for learner motivation toward iPads as language learning tools.

H12: Perceived usefulness has positive predictive value for learner motivation toward iPads as language learning tools.

H13 : Perceived satisfaction has positive predictive value for the effectiveness of iPads as learning tools.

H14: Perceived usefulness has positive predictive value for the effectiveness of iPads as learning tools.

H15 : Learner motivation has positive predictive value for the effectiveness of iPads as learning tools. 


\section{T. Grigoryan}

Firstly, the survey questionnaire was administered after the first phase of the experiment only to two iPad groups because that were exposed to iPads and had already formed attitudes towards the iPad use in language learning. Secondly, it was administered after the second phase of the experiment to the two iPad groups that were exposed to iPads in the second phase of the experiment. Each phase of the experiment lasted for 80 teaching periods. The time gap between the first-time and the secondtime survey administration was 80 teaching periods.

The survey questionnaire followed Robson's (2005) checklists: to help avoid problems in question wording (p. 245) and factors in securing a good response rate to a postal questionnaire (p. 249). No open-ended questions were used in this survey since the responses were expected to be 80 . Robson suggests the following: 'Cut down openended questions to a minimum with this type of questionnaire unless you can afford to spend a lot of time on analysis or have only a small number of responses to deal with' (Robson 2005, p. 245). This survey addressed nine factors:

1. Self-regulation

2. Self-efficacy

3. Interactive learning environments

4. Ease of iPad use

5. iPad-based tasks

6. Perceived satisfaction

7. Perceived usefulness

8. Motivation

9. Learning effectiveness

This nine-factor survey questionnaire used a seven-point Likert scale rating from completely disagree $=1$ to completely agree $=7$.

The questionnaire was revised based on Liaw and Huang's (2014) study and was designed to address Emirati students' perceptions of iPad use as a means of language learning. Initially, the survey underwent reliability checks and was piloted before it was administered. It was translated into Arabic which was the students' mother tongue. The purpose of Arabic translation was to minimise misunderstanding and misinterpretation of data. The survey employed the translation, review, adjudication, pretesting and documentation (TRAPD) method as suggested by the European Social Survey guidelines (Hoffmeyer-Zlotnik, Jürgen, and Warner 2014).

\section{Survey results}

After 80 responses were collected in two phases, factor analysis was run to identify traits from the administered question-level data (Table 4). Confirmatory factor analysis was done for each of the predetermined factors. Factors were rotated by applying Varimax method. Each item was loaded with a score greater than 0.3. As shown in Table 4, all items were retained except one loading 0.140 which was less than 0.3 . The excluded item was in the factor called 'perceived satisfaction' and was numbered as SATISF02. The item was excluded.

The overall reliability of all 29 items of the survey is 0.808 , which is greater than 0.7 , the minimum qualifying score. This means that the instrument is reliable (Appendix B). Kaiser-Meyer-Olkin's test and Bartlett's test of sampling adequacy showed 


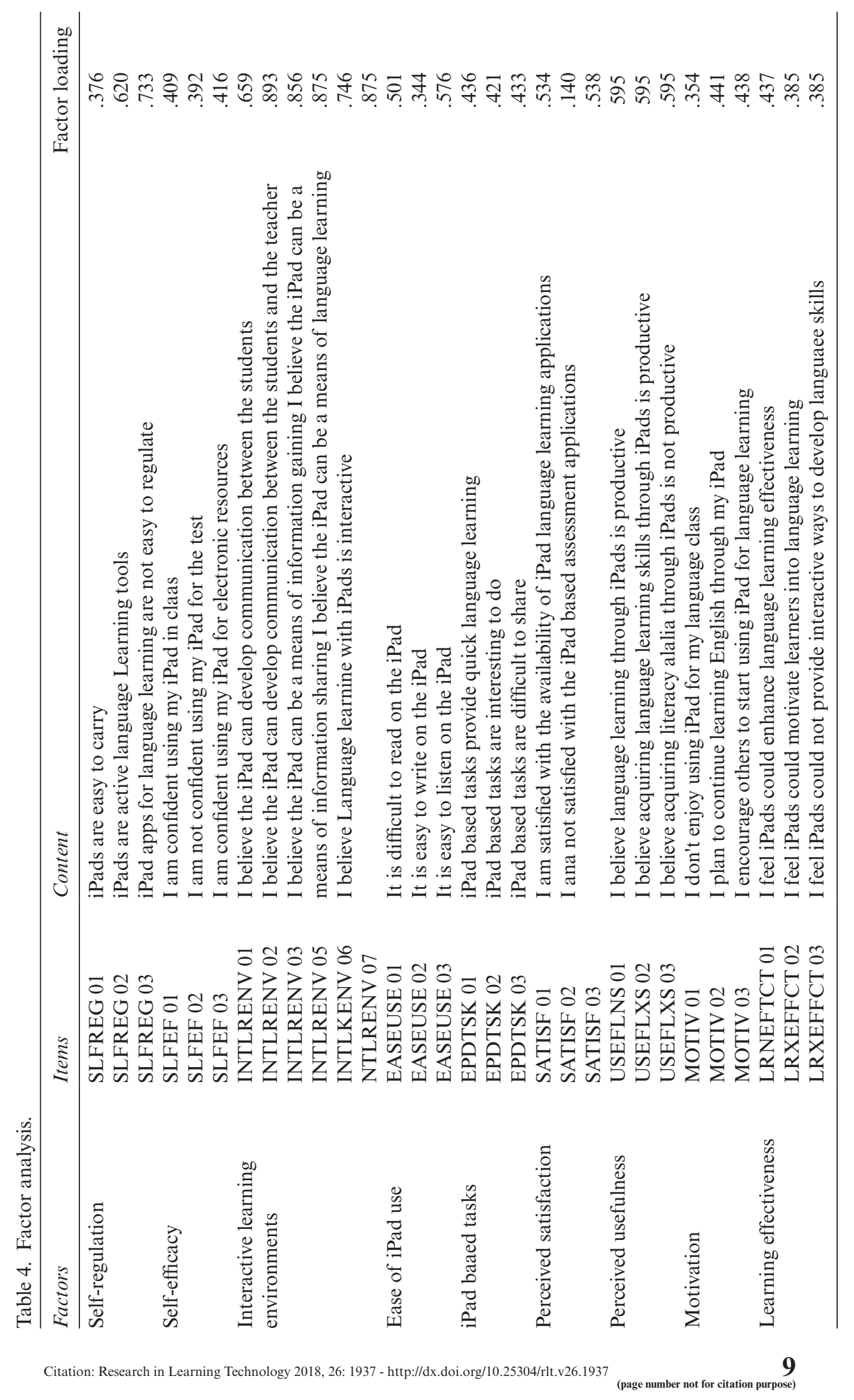




\section{T. Grigoryan}

a statistical value of 0.805 with $p=0$, which means the sample size was adequate for running the factor analysis. Exploratory factor analysis was done using principal component analysis method. Based on the eigenvalues greater than 1, five factors were extracted. These factors were rotated using Varimax method. Small coefficients with absolute value less than 0.3 were suppressed.

After the factor analysis a comparison of attitudes towards using iPads for language learning was carried out between $40 \mathrm{iPad}$ group students' responses from phase one and 40 iPad group students' responses from phase 2 (Table 5).

The aim of this statistical calculation was to see whether the responses were significantly different between the two phases and whether the students from phase 1 had different experience and attitudes towards iPad use compared with phase two students. As shown in the table, the sig. value for all factors is greater than 0.05 , which means there is no difference between the iPad group answers of phases 1 and 2 for any of the factors and the attitudes towards using iPads for language learning are similar in all four groups within both phases.

First, a comparison of attitudes towards using iPads for language learning was carried out between phases 1 and 2 with 40 iPad group students' responses each. Then, another comparison of attitudes was done, this time using both phases with 80 students' responses together as one (Table 6). The aim of this statistical calculation was to see the minimum and maximum grades of the factors and to identify the most and least favoured factors.

As shown in Table 6, for the seven-scale questionnaire, the average minimum score is 5 , which is above the average 4 .

1. Completely disagree

2. Mostly disagree

Table 5. Comparison of attitudes between iPad groups in phase 1 and iPad groups in phase 2.

\begin{tabular}{llcccc}
\hline Factors & $\begin{array}{l}\text { Groups in } \\
\text { phase 1 and 2 }\end{array}$ & Number & Mean & $\begin{array}{c}\text { Std. } \\
\text { deviation }\end{array}$ & Sig, value \\
\hline Self- regulation & iPad Groups & 40 & 6.6083 & .36893 & .142 \\
& iPad Groups & 40 & 6.7167 & .27786 & \\
Self-efficacy & iPad Groups & 40 & 6.4667 & .48803 & .768 \\
Interactive & iPad Groups & 40 & 6.5000 & .51750 & \\
learning & iPad Groups & 40 & 6.7333 & .29187 & .103 \\
environments & iPad Groups & 40 & 6.6042 & .40065 & \\
Ease of iPad use & iPad Groups & 40 & 6.6083 & .26026 & .155 \\
& iPad Groups & 40 & 6.5000 & .39943 & \\
iPad based tasks & iPad Groups & 40 & 6.8000 & .38895 & .051 \\
& iPad Groups & 40 & 6.5750 & .60500 & \\
Perceived & iPad Groups & 40 & 4.0125 & .21145 & .317 \\
satisfaction & iPad Groups & 40 & 4.0625 & .23170 & \\
Perceived & iPad Groups & 40 & 6.7625 & .46668 & .792 \\
usefulness & iPad Groups & 40 & 6.7375 & .37532 & \\
Motivation & iPad Groups & 40 & 6.9250 & .17683 & .189 \\
& iPad Groups & 40 & 6.8500 & .31078 & \\
Learning & iPad Groups & 40 & 4.9917 & .05270 & .051 \\
effectiveness & iPad Groups & 40 & 4.9500 & .12054 & \\
\hline
\end{tabular}


Table 6. Comparison of attitudes in two phases with four groups.

Survey 9 factors

\begin{tabular}{lcccccccccc}
\hline & $\begin{array}{c}\text { Self- } \\
\text { regalation efficacy }\end{array}$ & $\begin{array}{c}\text { Self- } \\
\text { Interactive } \\
\text { learning } \\
\text { environ. }\end{array}$ & $\begin{array}{c}\text { Ease } \\
\text { of } \\
\text { iPad } \\
\text { use }\end{array}$ & $\begin{array}{c}\text { iPad } \\
\text { based } \\
\text { tasks. }\end{array}$ & $\begin{array}{c}\text { Per- } \\
\text { ceived } \\
\text { J3lisf, }\end{array}$ & $\begin{array}{c}\text { Perceived } \\
\text { usefulness. }\end{array}$ & $\begin{array}{c}\text { Moti- } \\
\text { vation }\end{array}$ & $\begin{array}{c}\text { Lean- } \\
\text { ing } \\
\text { effective. }\end{array}$ \\
\hline $\mathbf{N}$ & 30 & $\mathrm{SO}$ & $\mathrm{SO}$ & 80 & $\mathrm{SO}$ & 80 & $\mathrm{SO}$ & $\mathrm{SO}$ & 80 \\
Mean & 6.6625 & $6.4 \mathrm{~S} 33$ & 6.6688 & 6.5542 & 6.6875 & 4.0375 & 6.7500 & 6.8875 & 4.9708 \\
Std. dev. & .32906 & .50007 & .35429 & .33937 & .51788 & .22183 & .42097 & .25405 & .09478 \\
Minimu m & 5.33 & 5.33 & 5.50 & 5.00 & 5.00 & 3.50 & 5.00 & 6.00 & 4.67 \\
Maximu m & 7.00 & 7.00 & 7.00 & 7.00 & 7.00 & 4.50 & 7.00 & 7.00 & 5.00 \\
\hline
\end{tabular}

Table 7. Test of normality.

\begin{tabular}{lcccccc}
\hline & \multicolumn{3}{c}{ Kolmogoro v-Smirno v } & \multicolumn{3}{c}{ Shapiro- Wilk } \\
\hline & Statistic & df & Sig. & Statistic & df & Sig. \\
\hline Interactive learning & .216 & 80 & .000 & .852 & 80 & .000 \\
Self-efficacy & .212 & 80 & .000 & .858 & SO & .000 \\
Satisfaction & .430 & 30 & .000 & .606 & 80 & .000 \\
Usefulness & .399 & 80 & .000 & .645 & 80 & .000 \\
IPad based tasks & .377 & SO & .000 & .657 & 80 & .000 \\
Motivation & .471 & SO & .000 & .504 & SO & .000 \\
Ease of use & .305 & SO & .000 & .775 & SO & .000 \\
LRNEFFECT & .533 & SO & .000 & .317 & SO & .000 \\
\hline
\end{tabular}

Lilliefors Significance Correction

3. Slightly disagree

4. Neither agree nor disagree

5. Slightly agree

6. Mostly agree

7. Completely agree

The highest minimum score among nine factors is 5 (slightly agree) and it is registered in the 'motivation' factor with the highest mean score of 6.8875 , which also shows the highest maximum score of 7 (completely agree). The lowest minimum score among nine factors is 3.50 (between slightly disagree and neither agree nor disagree) and it is registered in the 'perceived satisfaction' factor, which also shows the lowest maximum score of all, 4.50 (between neither agree nor disagree and slightly agree). This means that most of the students who received the questionnaire thought that iPads motivated them into language learning. However, they stayed neutral when it came to their satisfaction about using iPads for their language learning.

Test of normality was done on self-efficacy, self-regulation, interactive learning environments, ease of use, iPad-based tasks, perceived usefulness, perceived satisfaction, motivation and learning effectiveness (Table 7). 


\section{T. Grigoryan}

As shown in Table 7, the variables do not follow normal distribution. All Sig. values are less than 0.05 , which means variables are not normally distributed. Because the variables were not normal, parametric regression analysis was not applicable. Since the aim of the research was to establish a path model, structural equation modelling (SEM) was done using the AMOS software (Figure 1).

Then the regression weights were calculated and hypotheses were set (Table 8).

Table 9 illustrates the tested and the accepted hypotheses. As shown in the table, self-regulation showed positive effect on students' satisfaction and perceived tool usefulness. Interactive learning environment and self-efficacy have positive effect on perceived usefulness. Perceived usefulness has positive effect on motivation, which in turn has positive effect on learning effectiveness. These factors are interconnected and have positive effect on each other according to the survey questionnaire analysis.

\section{Reflective journals}

The qualitative analysis was performed through weekly reflective journal logs used by the teachers to record the procedure of the teaching and learning process for all four groups (Table 10). The two data sources that informed this part of the study were soft copies of four teachers' weekly written reflections in phase 1, which lasted for 4 weeks, and soft copies of two teachers' weekly written reflections in phase 2, which lasted for another 4 weeks. This means that four teachers teaching four groups for 4 weeks wrote 16 journals in phase 1 , and two teachers teaching two groups for another 4 weeks wrote eight journals in phase 2 . By the end of the experiment, the teachers produced 24 reflective journals. The descriptive journals were standardised through team meetings and contained information about 80 teaching periods with four groups and another 80 teaching periods with two groups. They were divided into three sections. Section 1 contained information about the work plan, such as details about the unit, learning outcomes and skills to be taught. In section 2, teachers wrote about what they covered within the week. In section 3, they reflected on their teaching and students' learning (Appendix A).

The journal summaries showed the advantages and disadvantages of the methods and ways the material was introduced by the teachers and reproduced by the

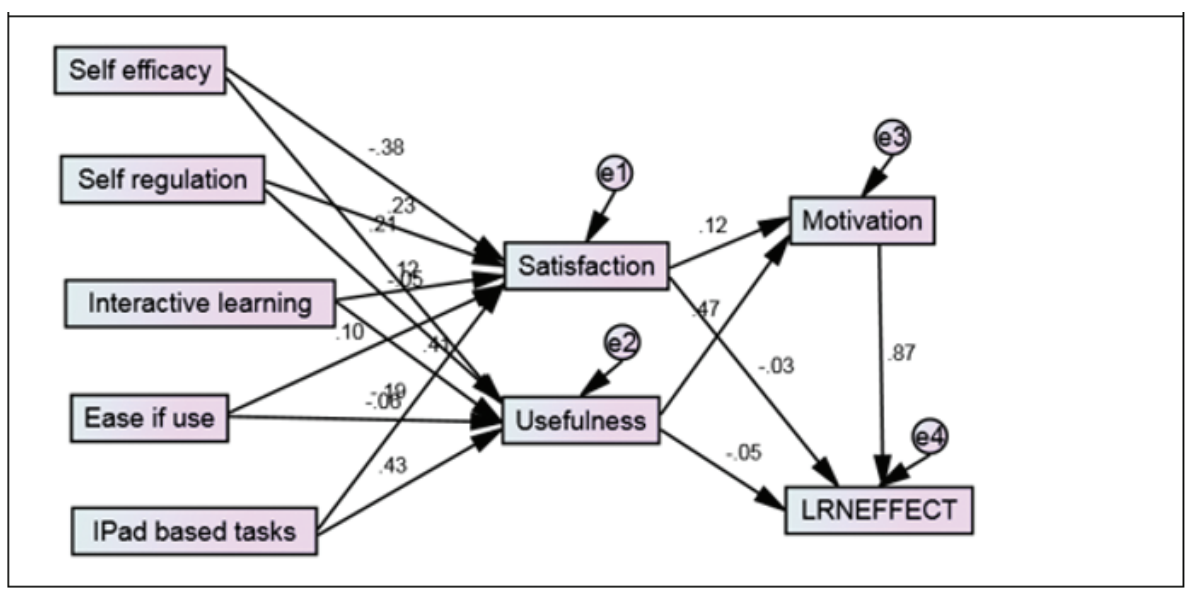

Figure 1. Path model. 
Table 8. Regression weights.

\begin{tabular}{|c|c|c|c|c|c|c|c|}
\hline & & & Estimate & S.E. & C.R. & $\mathbf{P}$ & Label \\
\hline SATISF & $<-$ & SLFEF & -.177 & .045 & -3.933 & $* * *$ & pari \\
\hline SATISF & $<-$ & SLFREG & .163 & .068 & 2.385 & .017 & par_2 \\
\hline USEFLN & $<-$ & INTLERN & .415 & .089 & 4.670 & ***** & par_3 \\
\hline SATISF & $<-$ & INTLERN & .078 & .063 & 1.229 & .219 & par_4 \\
\hline USEFLN & $<-$ & EASU & -.067 & .093 & -.722 & .470 & par_5 \\
\hline USEFLN & $<-$ & IPDTSK & .299 & .061 & 4.910 & $* * *$ & par 6 \\
\hline SATISF & $<-$ & EASU & .068 & .066 & 1.032 & .302 & par_7 \\
\hline SATISF & $<-$ & IPDTSK & -.083 & .043 & -1.913 & .054 & par_8 \\
\hline USEFLN & $<-$ & SLFEF & .152 & .063 & 2.411 & .016 & par_14 \\
\hline USEFLN & $<-$ & SLFREG & -.053 & .096 & -.550 & .582 & par_15 \\
\hline MOTTV & $<-$ & USEFLN & .321 & .068 & 4.696 & $* * *$ & parl O \\
\hline MOTTV & $<-$ & SATISF & .123 & .107 & 1.156 & .247 & parl 1 \\
\hline LRNEFFECT & $<-$ & USEFLN & -.012 & .017 & -.715 & .474 & par_9 \\
\hline LRNEFFECT & $<-$ & SATISF & -.013 & .024 & -.538 & .590 & par_12 \\
\hline LRNEFFECT & $<-$ & MOTTV & .329 & .025 & 13.020 & & par 13 \\
\hline
\end{tabular}

Table 9. The tested and accepted hypothesis.

H1 : Perceived self-efficacy has positive predictive value for perceived satisfaction toward iPads as language learning tools.

$\mathrm{H}$ 2: Perceived self-efficacy has positive predictive value for perceived usefulness toward iPads as language learning tools.

H3: Perceived self-regulation has positive predictive value for perceived satisfaction toward iPads as language learning tools.

H4: Perceived self-regulation has positive predictive value for perceived usefulness toward iPads as language learning tools.

H5: Interactive learning environment have positive predictive value for perceived satisfaction toward iPads as language learning tools.

H6: Interactive learning environments have positive predictive value for perceived usefulness toward iPads as language learning tools.

H7: Perceived ease of use has positive predictive value for perceived satisfaction toward iPads as language learning tools.

H8: Perceived ease of use has positive predictive value for perceived usefulness toward iPads a3 language learning tools.

H9: iPad based tasks have posith- e predictive value for perceived satisfaction toward iPads as language learning tools.

H10: iPad based tasks have positive predictive value for perceived usefulness toward iPads as language learning tools.

H11: Perceived satisfaction has positive predictive value for learner motivation toward iPads as language learning tools.

H12: Perceived usefulness has positive predictive value for learner motivation toward iPads as language learning tools.

H13: Perceived satisfaction has positive predictive value for the effectiveness of iPads as learning tools.

H14: Perceived usefulness has positive predictive value for the effectiveness of iPads as learning tools.

H15: Learner motivation has positive predictive value for the effectiveness of iPada as learning tools. 
Table 10. Summary of reflections.

Summar y of positive an d negative teacher reflections from two experimental phases|

\begin{tabular}{|c|c|c|}
\hline & Positive reflections & Negative reflections \\
\hline $\begin{array}{l}\text { iPad based } \\
\text { classes }\end{array}$ & $\begin{array}{l}\text { Learning became alive for the } \\
\text { students while they were creating } \\
\text { something that was new and } \\
\text { meaningful to them. } \\
\text { One of the tasks they enjoyed } \\
\text { doing was the iMovie project } \\
\text { which they did in pairs. } \\
\text { They liked working with the } \\
\text { interactive textbook. } \\
\text { To practice this grammar aspect } \\
\text { we downloaded Tense Buster } \\
\text { app and successfully practiced } \\
\text { it through various interactive } \\
\text { exercises. } \\
\text { I was impressed with the mini } \\
\text { projects that the pairs quickly } \\
\text { and easily produced through the } \\
\text { iMovie. Not only the unit vocab- } \\
\text { ulary and grammar were mostly } \\
\text { used accurately, the mood and } \\
\text { motivation apparently took over } \\
\text { the hard work. } \\
\text { On this note I will say I had } \\
\text { a strong feeling that students } \\
\text { made friends with iPads and } \\
\text { found it easy to work with them } \\
\text { to achieve their goals. } \\
\text { The interactive exercises allowed } \\
\text { students to redo the difficult } \\
\text { parts and get immediate auto } \\
\text { feedback. } \\
\text { Comprehension checks were } \\
\text { done through collaborative } \\
\text { tasks; asking and answering } \\
\text { questions and sharing stu- } \\
\text { dents' voice recordings with the } \\
\text { teacher. } \\
\text { I felt my students enjoyed their } \\
\text { learning this week and were on } \\
\text { task at all times. }\end{array}$ & $\begin{array}{l}\text { Students had some issues with op- } \\
\text { erating the programs and needed } \\
\text { assistance. } \\
\text { Though we had couple of tech- } \\
\text { nical glitches with iPad apps and } \\
\text { e-book codes, we successfully went } \\
\text { through this first week. } \\
\text { I had two students constantly } \\
\text { asking for permission to write } \\
\text { on a paper. They explained that } \\
\text { they got irritated when writing on } \\
\text { the screen and that the space for } \\
\text { writing was too small. } \\
\text { Though they were not quite happy } \\
\text { and willing to work on iPads, they } \\
\text { tried to do their best. } \\
\text { In the beginning, for some of } \\
\text { us it [a new app] was difficult to } \\
\text { operate and we wanted to give } \\
\text { up. A student then insisted and } \\
\text { suggested to explore the settings } \\
\text { and options and to } \\
\text { consider doing a dry run with the } \\
\text { peers to iron out the kinks. } \\
\text { It was a transition for this class } \\
\text { from paper based to iPad based } \\
\text { learning. Therefore, some of the } \\
\text { students took quite long to adjust. } \\
\text { There were also negative reactions } \\
\text { this week: a student was really } \\
\text { upset when she accidentally de- } \\
\text { leted her work that she spend con- } \\
\text { siderable time on. I tried to bring } \\
\text { it back but was not successful. } \\
\text { Another case was with the paid } \\
\text { apps. Some students didn't have } \\
\text { credit cards to purchase those } \\
\text { apps we needed in class and had } \\
\text { to use the free ones which didn't } \\
\text { hal-e all the necessary functions. }\end{array}$ \\
\hline
\end{tabular}

- Every time I saw students had problems understanding a language aspect (ex. subject - verb agreement), I created activities from online resources $\mathrm{cm}$ spot 
Table 10. (Continued)

\begin{tabular}{|c|c|c|}
\hline \multicolumn{3}{|c|}{ Summar y of positive an d negative teacher reflections from two experimental phases| } \\
\hline & Positive reflections & Negative reflections \\
\hline $\begin{array}{l}\text { ook bas } \\
\text { lasses }\end{array}$ & $\begin{array}{l}\text { Students effectively completed } \\
\text { all reading activities in groups } \\
\text { or pairs. } \\
\text { The group successfully worked } \\
\text { with the book exercises and } \\
\text { completed all of them individu- } \\
\text { ally, in pairs and in groups. } \\
\text { We conducted discussions about } \\
\text { the school day length and time } \\
\text { for homework and fun. Students } \\
\text { were quite active in expressing } \\
\text { their opinions and volunteering } \\
\text { to contribute to the discussion. } \\
\text { They had fun and tried their } \\
\text { best to express themselves to } \\
\text { introduce their friends through } \\
\text { the project they did in pairs. } \\
\text { They used their notes and vo- } \\
\text { cabulary logs to express opinion } \\
\text { and bring reasons for their } \\
\text { answers. } \\
\text { They enjoyed working in pairs } \\
\text { and planning a tour of their } \\
\text { college. They drew a map and } \\
\text { decided where the tour began } \\
\text { and ended, and what places had } \\
\text { to be on the tour. } \\
\text { Vocabulary building was } \\
\text { discussed this time through the } \\
\text { dictionary entries. They enjoyed } \\
\text { looking through thick dictionar- } \\
\text { ies and searching for words. } \\
\text { Before writing the paragraphs } \\
\text { they learned how } \\
\text { to write idea maps and use them } \\
\text { for writing. They actually did it } \\
\text { very well. } \\
\text { In the end I asked my students } \\
\text { to say what they thought about } \\
\text { their friends' poster presenta- } \\
\text { tions and voted for the best one. } \\
\text { It was a nice experience. }\end{array}$ & $\begin{array}{l}\text { JThe book activities were not } \\
\text { enough to practice and under- } \\
\text { stand Present of be and I brought } \\
\text { in extra materials every day. } \\
\text { They easily got tired of the } \\
\text { textbook but had fun with the } \\
\text { new listening exercises and } \\
\text { discussions. } \\
\text { I felt classes were long and } \\
\text { boring for the students and they } \\
\text { complained about not having } \\
\text { interesting exercises in the book. } \\
\text { I tried to make the textbook more } \\
\text { interesting for them by creating } \\
\text { competitions and games, which } \\
\text { took lots of effort and time to } \\
\text { think and constantly come up } \\
\text { with something. } \\
\text { Another drawback was the } \\
\text { grammar issue with do and does. } \\
\text { I had to create extra materials } \\
\text { and adapt exercises, print, cu t } \\
\text { and prepare them for group or } \\
\text { pair work. I wouldn't go through } \\
\text { this if students had interactive } \\
\text { e-textbooks of course. } \\
\text { When I asked them why they } \\
\text { were so happy and enthusiastic } \\
\text { about the project they simply rea- } \\
\text { soned that it was different from } \\
\text { the boo k } \\
\text { The units were long and the } \\
\text { students hardly managed to com- } \\
\text { plete all tasks and exercises from } \\
\text { both books. } \\
\text { Grammar took little bit longer } \\
\text { than expected because each and } \\
\text { every student needed feedback on } \\
\text { any written piece produced. } \\
\text {.. . the biggest concern of the } \\
\text { week for me was the lack of time. }\end{array}$ \\
\hline
\end{tabular}

students. According to Lamb (2013), 'Reflecting on different aspects of the research process when writing a research journal provides a forum to record concerns which may have otherwise been lost or simply not considered' (p. 85). 


\section{T. Grigoryan}

\section{Reflective journal results}

The aim of the reflective journal data analysis was to identify the themes and patterns that were grounded in the data (Corbin and Strauss 2008) and gain insights from level 1 teachers' reflections through weekly journal entries. The study used Grounded theory and constant comparative method to analyse the data, as they aimed at generating a theory that was grounded in the data from the participant teachers who had experienced and reflected on the process.

The first step was reading the reflections from beginning to end many times trying to understand the mood, feelings and experiences of the participants. With the second step, each section was examined in detail and memos were written. Memos helped to form ideas and keep track of thinking about various matters. Methodological notes were also inserted between the memos to explain, differentiate and understand how they fitted together.

After the open coding, the concepts were related. Next, the core concepts were identified from the coded data categories and subcategories through open and axial coding. Finally, selective coding was done. When selecting and relating categories in this final step, two core concepts were revealed in the context of learning, language learning and motivation, which eventually became the selective codes. These two selective codes were then inserted into the AT of using two methods in language teaching, iPad based and textbook based, and were analysed through multivariate angles of that framework.

Though tools exist whenever people are involved in specific activities, they are also created through those activities. Therefore, a mediating action consists of a subject, an object and tools that are continuously transformed through the activity. This view of a mediated activity draws on a theory of learning that looks at language learners as subjects who actively construct meaning within the context. In this study, the facilitator is the method and subjects are language learners. The context of learning involves the two core concepts that emerged from the coded data categories: motivation and learning. They are to transform the object into an outcome.

In this study, the AT of using two methods for language learning - iPad-based and textbook-based language learning - starts out from the idea that students start using the methods in the context of their participation in language learning activities. Hence, language learning is a mode of activity that can be characterised through a method that describes how the activity in general is accomplished. To describe this accomplishment, two conceptual models of AT have been formed based on two methods: iPad-based and textbook-based language learning (Figures 2 and $3)$.

The models look at the activity as a purposeful, productive process carried out by subjects, who are 80 beginner-level language learners placed in four homogeneous groups, on an object, which is language achievement, via two mediating tools: iPads and textbooks (Engestrom 1999). The subject, object and tool are observed within the context of a teaching-learning process, in which activity is embedded. In the AT triangle, the control of learning is iPad-based versus textbook-based tasks, and the communication of learning is interactive versus traditional learning environment. In this section of reflective journal analysis of the study, these six elements comprise and govern the activity system. This practical view of the activity with emphasis on the mediating tools makes the AT well suited for the analysis of process and activities involving significant components in higher education (Khanova 2012). 


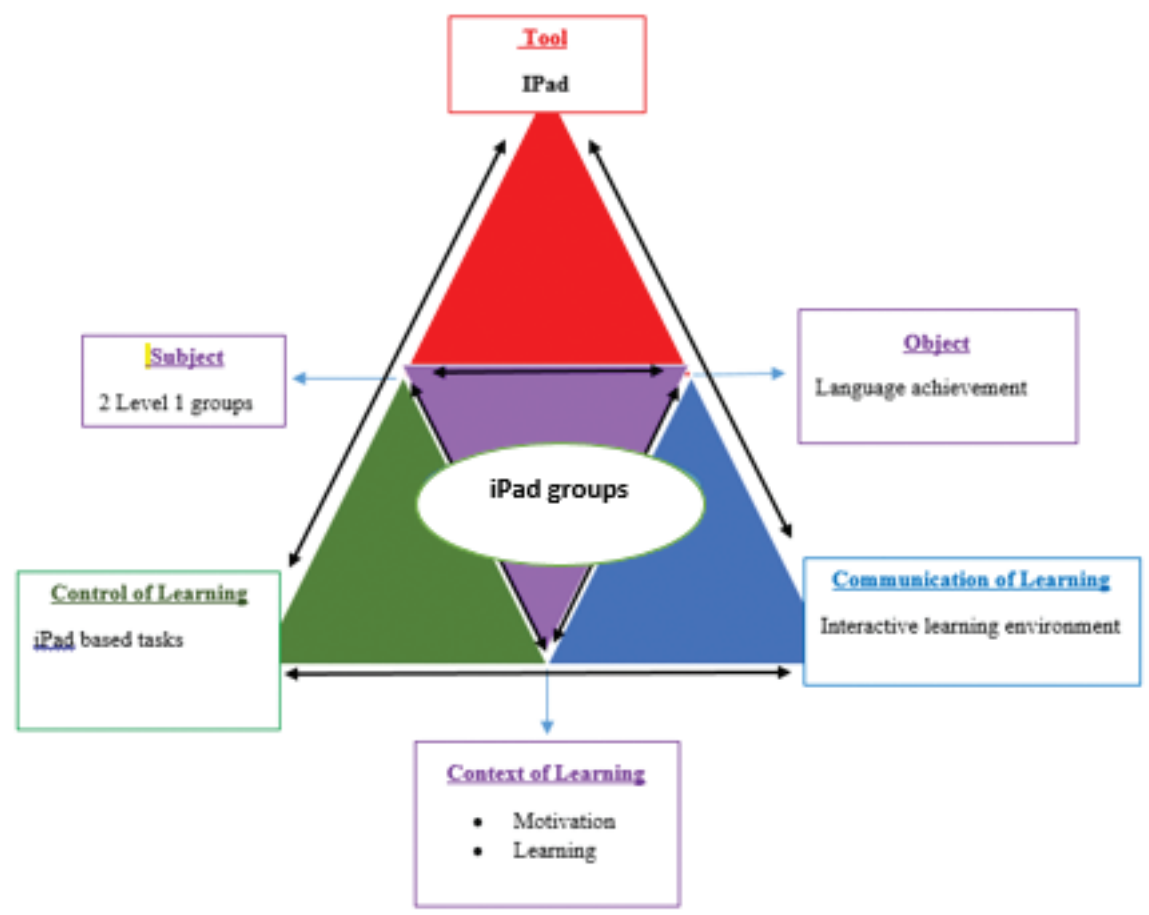

Figure 2. Activity theory conceptual model of iPad-based language learning.

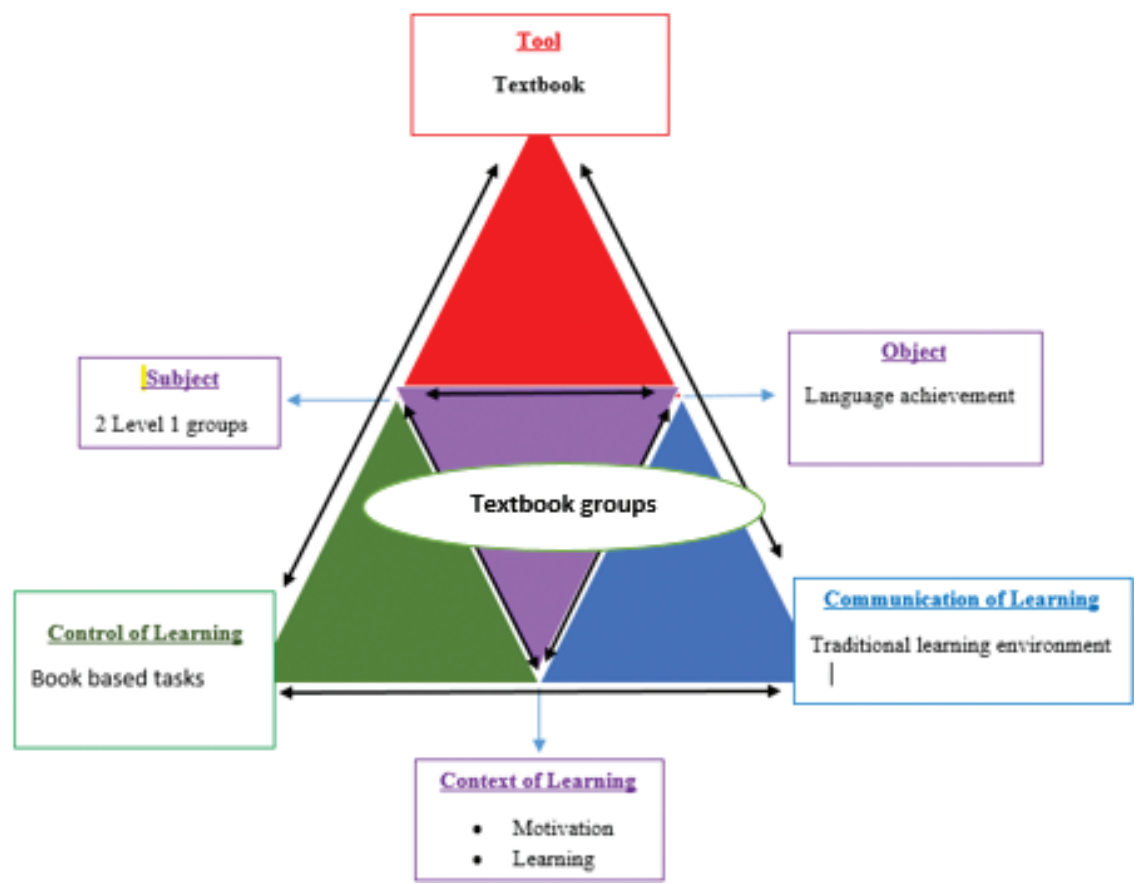

Figure 3. Activity theory conceptual model of textbook-based language learning. 


\section{T. Grigoryan}

The reflective journals, which were analysed through AT loops, showed that the language achievement is more enjoyable when iPads are used as a means of learning. The level 1 language learners experienced the digital world for learning the target language that was completely out of sync with traditional approaches and assumptions about teaching, learning, giving feedback or assessing. Despite the best of intentions to teach the language through traditional methods, the textbook-based teaching and learning did not really connect with modern language learners primarily because the traditional methods were targeted at learners from another age. As reflected in the journals, the students wanted their learning to be relevant, fast, applicable and instantly useful. What is more is that they wanted to know the possible relevance of learning specific language aspects for them and their world and why it could not be fun most of the time.

While some experts may argue that the experiences the digital generation have are worthless and that play and games are simply preparation for work and life after school, for today's digital generation, play is work, and work is increasingly seen in terms of games and game play. (Jukes, McCain, and Crockett 2010, p. 41)

Another interesting point raised in the journals was the constant complain of the textbook group students about not receiving immediate feedback to the completed work and teachers not being able to give enough of the class time for individual feedback to students after every language task. The clue here is that the digital world presents the students with a direct link between the effort taken and the reward received, whereas the feedback or the reward given by the teachers in the traditional classroom during the experiment was either too nebulous or too slow to motivate students to keep the pace of progressive learning. It must be mentioned that unlike the textbook groups, iPad groups had no issues connected with the pace of receiving feedback or waiting for their work to be checked. As Jukes, McCain, and Crockett (2010) mention,

A direct connection between effort and reward, immediate or deferred, is why digital culture resonates so strongly with the digital generation. In terms of immediate rewards, digital culture provides them with exactly what they not only want, but what they need most _ positive feedback. (p. 40)

\section{Discussion}

Through the survey data analysis, the study recorded positive student attitudes towards iPad implementation as a language learning tool in terms of learner satisfaction, motivation, perceived tool usefulness and learning effectiveness.

The perceived self-efficacy, which referred to students' beliefs in their capacity to execute behaviours necessary to produce specific language performance, had negative effects on perceived satisfaction, which supposed the fulfilment of their expectations. On the other hand, the fulfilment of their expectations was encouraged by their self-regulation, that is to say, by their ability to monitor and control their own behaviour and learning habits through iPads. In other words, students were happy with the control they had over their learning through iPads as a means of learning. The perceived usefulness was the fundamental determinant of user acceptance. It was positively affected by the interactive learning environments, which was the pedagogical approach that incorporated virtual networking and communication by students. Interestingly, according to the survey results, neither the interactive learning environment nor the ease of iPad use had any effects on students' satisfaction 
of the device being implemented in their education. The ease of iPad use, which was the user-friendly operational system, had negative effect on the perceived usefulness. In other words, students did not see it as a useful learning tool because of its user-friendliness. On the contrary, the iPad-based tasks had a positive effect on the perceived usefulness. This means students saw the iPad as a useful learning tool because of the learning it was able to provide through online tasks. The self-regulation had positive effect on students' satisfaction and perceived tool usefulness. In other words, working with iPads raised students' satisfaction level as well as their level of language achievement. Students felt positive studying paperless and did their best to achieve success. They were satisfied and positive about this method of learning because they could regulate their device to serve their individual learning needs and pace. Because students were able to manipulate the electronic applications and multitask, they were happy with what they learned and, hence, accepted iPads as a means of learning.

Interactive learning environment had positive effect on perceived usefulness. Moreover, self-efficacy had positive effect on perceived usefulness. This means that interactive learning environment, which is seen as communication between students, as well as between students and the teacher, made students positive about the usefulness of iPads as a means of language learning. iPads played a major role in how students efficiently approached their goals, overcame challenges, solved problems and completed various language tasks. Therefore, self-efficacy, which is considered as students' beliefs in their ability to succeed in language learning, helped them understand the importance and usefulness of the device.

Perceived usefulness had positive effect on motivation, which in turn had positive effect on learning effectiveness. This is like a chain reaction in a sense that students' positive attitudes towards iPad use as a means of language learning motivated them into learning the target language, which resulted in higher language achievement and effectiveness. Perceived usefulness motivated them into accomplishing language tasks and overcoming language difficulties by the help of the paperless learning. Moreover, motivation and learning effectiveness resulted from the interaction of learning needs and positive outcomes that students had towards the accomplishment of language tasks. Therefore, it must be stated that according to the survey analysis, iPads stimulate students' desire and energy to keep them continuously interested in and committed to language learning tasks, assignments, projects and other language learning requirements and make efforts to attain the goals.

Not only the survey results but also the reflective journal analysis showed that iPad-based language learning is more productive than textbook-based language learning. The reflective journals that the four teachers involved in the experiment completed throughout the two phases revealed that the interactive learning environment in both phases showed quite a high level of student motivation and language achievement.

The activity of learning through textbooks as compared to iPads, which was undertaken by the same subjects using two different tools in two different phases to achieve the same object, transformed it into an outcome in both phases and demonstrated positive results regardless of whether it was textbook related or technological challenges. However, as the 24 reflective journals showed, iPad-based learning carried more benefits than textbook-based learning in terms of motivation and learning effectiveness. Therefore, the language achievement is fun when iPads are used as a 


\section{T. Grigoryan}

means of language learning. However, this is not to say that the skills and knowledge traditionally used or taught in the 20th century are obsolete today. Much educational practice developed and used in the 20th century are effective nowadays and some of them are more effective than before. However, as the results of this study highlight, there has been a change in emphasis in what is essential for success, and a completely different skill set is required to live and learn in the modern digital world, such as information, solution, collaboration, creativity and media fluencies (Jukes, McCain, and Crockett 2010). Unlike in the past, when students had to be patient and wait until they could get a chance to use whatever they had learnt in real life, today's digital native students can easily and daily experience direct connections. They can participate in profound social revolutions like crowdsourcing and personally significant ones like online voting. Above all, these students are in favour of digital devices because in the digital world they can easily cooperate, compete, share and learn with their peers around the world. This is what the results of this study highlighted.

\section{Recommendations}

In this information and technology era, regardless of their preferred professions, graduates are facing growing demands to have high level of English communication skills, in addition to their majors, before entering the workforce. However, many students face difficulties meeting their needs within the limited class hours during their education. To overcome these challenges, many learners are implementing mobile technologies in their language learning as well as in other discipline areas. The reason of using mobile technologies is that they provide facility to access to authentic materials. Though this study showed that it is enjoyable to use mobile technology and particularly iPads in language learning, it did not widen the scope of looking at different levels of English proficiency. Therefore, a further study should concentrate on higher levels of English proficiency paperless classrooms and compare iPad-based learning with other traditional methods.

This study concentrated on Emirati female students only. Hence, it would be interesting to investigate the ways that integration of mobile technology can change the learning outcomes and attitudes of other nationality second language learners' English proficiency. In addition, it would be interesting to see whether gender plays a significant role in studying with mobile devices. Moreover, it would be productive to experiment with iPad-related specific tasks and applications to see which exact language tasks, practices and skills can boost higher language achievement.

\section{Limitations}

This study had a number of anticipated and unanticipated limitations; however, where possible, steps were taken to control or prevent them. Though the students were randomly selected, by coincidence there were groups which had students with special needs. To control this limitation, simple main effect analysis was run to determine the mean difference between groups of students who scored at high, average and low levels on the pretest.

Another limitation of the study was out-of-class iPad use. Since this study was based on in-class teaching and learning process, it did not consider out-of-class iPad use. However, this limitation could only be partially controlled by simply banning the language apps planned for in-class use from out-of-class use through the Guided 
Access code control. By setting those codes on students' iPads, teachers stopped students from using their iPads for language learning unless the codes were changed. A further limitation that was anticipated was the communication and information exchange between the students during the breaks. Since all four groups under experiment were in the same college and students shared the same eating and resting areas, they met and communicated. To partially control this limitation, students were informed about the experiment, asked to assist in conducting it and signed a consent form.

\section{Conclusion}

Today's language classroom is undergoing an irreversible revolution and one of the most powerful drivers of this transformation is information and communication technologies. According to Ouchi and Segal (2003), 'Revolutionary change requires the perception that there is a crisis' (p. 246). Some teachers would appear to have doubts about reforms as they fear the chaos that innovations might bring. Moreover, they are afraid that the innovative change in the curriculum could grow into their idea of hell. However, today's students are 'digital natives' and today's teachers need to listen to the kids they teach (Prensky 2012, p. 105). This study provided evidence of the kind of learning that has a positive impact on language learners' attitudes towards the paperless method. iPad-based language learning tasks and assignments were a useful way to spark learners' interest, motivation and enthusiasm, and the interactive environment could make it easy for the students to settle down, concentrate and do their best in learning a foreign language. The students who are given freedom and choice to explore and create in whatever academic ways they want to as part of their learning coursework are far more willing and motivated than those who do not have this freedom. The pleasure of observing, grading, evaluating and giving feedback on these efforts must be extremely rewarding for both teachers and students. Teachers are encouraged to give students as much latitude and support as possible for their creative efforts, continuously setting the bar higher and higher and ensuring all efforts get shared with the rest of the class.

The medium of instruction in UAE higher education degree programmes is English. The medium of instruction in the UAE public primary and secondary programmes, on the other hand, is Arabic. Since English is taught as a foreign language, this makes it difficult and extremely challenging for the UAE high school graduates to study degree programmes delivered through this medium. Therefore, this study was designed and conducted as a response to the need to improve Emirati language learners' English proficiency and prepare them for undergraduate education delivered through English.

According to Gitsaki, Robby, and Bourini (2014), 'Often the problem is addressed by having high-school graduates attend long post-secondary academic bridging courses in preparation for higher education, but this reduces student motivation'. (p. 168). As Jukes, McCain, and Crockett (2010) mention, 'Children today are different' (p. 20). Based on the observations of these scholars, it must be mentioned that children are different in the ways they think, process or view the world. These differences are the influences of the digital world they live in today and what is more is that it holds insightful implications for teachers personally and professionally. The students' experience away from school is highly visual. It is the world of online information which does not involve traditional reading, writing or even traditional ways of thinking. Today's language learners in the class are not the readers and writers the system is 


\section{T. Grigoryan}

designed for, nor are they the readers and writers most teachers have been trained to teach. Above all, they are equipped with 21 st century skills that enable them to process audio and visual information more effectively than traditional texts. What is more is that they are used to getting this information in an interactive environment where they are given ample opportunity to regulate it to serve their needs and experience. As said by Jukes, McCain, and Crockett (2010), 'Asking today's students to sit while teachers talk or to do the traditional reading of long passages of uninterrupted text is like trying to fit a round peg in a square hole' (p. 122). In order to motivate students for learning a foreign language, it is necessary to make them feel that the way they are acquiring it is relevant to the online visual world that awaits them when the language course is completed. According to the findings of this study, students' motivation could be boosted by providing them with iPad-based language learning, which will assist in shorter term language progression and be more effective than the traditional paperand-pen methods. Hence, long post-secondary academic bridging programmes could easily be replaced by short post-secondary paperless academic bridging programmes.

\section{References}

Bandura, A. (1999) Self-efficacy in Changing Societies, Cambridge University Press, New York.

Bandura, A. (2002) 'Social cognitive theory in cultural context', Applied Psychology: An International Review, vol. 51, no. 2, pp. 269-290.

Boczkowski, P. J. (2010) 'The mutual shaping of technology and society in videotex newspapers: beyond the diffusion and social shaping perspectives', The Information Society, vol. 20, no. 2, pp. 225-267.

Chiu, C., Hsu, M. \& Wang, E. (2006) 'Understanding knowledge sharing in virtual communities: an integration of social capital and social cognitive theories', Science Direct, vol. 42, no. 1 , pp. $1872-1888$.

Churchill, D. \& Wang, T. (2014) 'Teacher's use of iPads in higher education', Educational Media International, vol. 51, no. 3, pp. 214-225.

Cooke, R. \& French, D. P. (2008) 'How well do the theory of reasoned action and theory of planned behaviour predict intentions and attendance at screening programs? A meta-analysis', Psychology and Health, [online] Available at: http://www.tandfonline.com/loi/gpsh20

Corbin, J. \& Strauss, A. (2008) 'Basics of Qualitative Research. Techniques and Procedures for Developing Grounded Theory'. Los Angeles: SAGE

Dan, D. (2002) 'The paperless classroom: e-filing and e-valuating students' work in English composition', Teaching English in the Two-year College, vol. 30, no. 2, pp. 162-178.

Doane, A. N., Pearson, M. R. \& Kelley, M. L. (2014) 'Predictors of cyberbullying perpetration among college students: an application of the theory of reasoned action', Computers in Human Behaviour, vol. 36, no. 1, pp. 154-162.

Engestrom, Y. (1999) Perspectives on Activity Theory, Google Books, Cambridge University Press, Cambridge

Enriquez, A. (2010) 'Enhancing student performance using tablet computers', College Teaching, vol. 58, no. 3, pp. 77-84.

Fishbein, M. \& Ajzen, I. (2010) Predicting and Changing Behaviour, The Reasoned Action Approach, Taylor and Francis Group, New York.

Flick, U. (2006) The SAGE Dictionary of Social Research Methods, SAGE, London.

Ghezzi, A., Rangone, A. \& Balocco, R. (2013) 'Technology diffusion theory revisited: a regulation, environment, strategy, technology model for technology activation analysis of mobile ICT', Technology Analysis \& Strategic Management, vol. 25, no. 10, pp. 1223-1249.

Gitsaki, C. \& Robby, M. A. (2014) 'Post-Secondary students using the iPad to learn English: an impact study', Journal of Mobile and Blended Learning, vol. 6, no. 4, pp. 1-22. 
Gitsaki, C., et al., (2013) 'A research agenda for the UAE iPad initiative', Gulf Perspectives, vol. 10, no. 2, [online] Available at: http://the.zu.ac.ae

Gitsaki, C., Robby, M. A. \& Bourini, A. (2014) 'Preparing Emirati students to meet the English language entry requirements for higher education: a pilot study', Journal of Education, Business and Society, Contemporary Middle Eastern Issues, vol. 7, no. 2, pp. 167-184.

Gong, M., Xu, Y. \& Yu, Y. (2004) 'An enhanced technology acceptance model for Web-based learning', Journal of Information Systems Education, vol. 15, no. 4, pp. 365-374.

Hoffmeyer-Zlotnik, J. H. P. \& Warner, U. (2014) Harmonizing Demographic and Socio-Economic Variables for Cross-National Comparative Survey Research, Springer, New York.

Jukes, I., McCain, T. \& Crockett, L. (2010) Understanding the Digital Generation, Corwin, Canada.

Khanova, J. (2012) Moving Courses Online as a Catalyst of Pedagogical Innovation: An Activity Theory Based View, School of Information and Library Science, University of North Carolina, US

Lai, C., Shum, M. \& Tian, Y. (2014) 'Enhancing learners' self-directed use of technology for language learning: the effectiveness of an online training platform', Computer Assisted Language Learning, vol. 29, no. 1, pp. 40-60.

Lamb, D. (2013) 'Promoting the case for using a research journal to document and reflect on the research experience', Electronic Journal of Business Research Methods, vol. 11, no. 2, pp. 84-92.

Liaw, S. \& Huang, H. (2014) 'Investigating learner attitudes toward e-books as learning tools: based on the activity theory approach', Interactive Learning Environments, vol. 10, no. 9, pp. $10-80$.

Limayem, M., Hirt, S. G. \& Cheung, C. M. K. (2007) 'How habit limits the predictive power of intention: the case of information systems continuance', MIS Quarterly, vol. 31, no. 4, pp. 705-737.

Meder, A. M. \& Wegner, J. R. (2015) 'iPads, mobile technologies, and communication applications: a survey of family wants, needs, and preferences', Augmentative and Alternative Communication, vol. 31, no. 1, pp. 27-36.

Mishra, D., Akman, I. \& Mishra, A. (2014) 'Theory of reasoned action application for green information technology acceptance', Computers in Human Behaviour, vol. 36, no. 1, pp. 29-40.

Ouchi, W. G. \& Segal, L. G. (2003) Making Schools Work, Simon \& Schuster, New York.

Prensky, M. (2001) 'Digital natives, digital immigrants', NCB University Press, vol. 9, no. 5, pp. $1-6$.

Prensky, M. (2012) Teaching Digital Natives: Partnering for Real Learning, Corwin, Thousand Oaks, CA, California.

Robson, C. (2005) Real World Research, Blackwell Australia.

Rogers, E. M. (2003) Diffusion of Innovation, 5th edn, Free Press, New York.

Roth, W. M., Radford, L. \& LaCroix, L. (2012) 'Working with cultural-historical activity theory', Qualitative Social Research, vol. 13, no. 2, pp. 1-15.

Swearer, S. M., et al., (2014) 'Reducing bullying: application of social cognitive theory', Theory into Practice, vol. 53, no. 1, pp. 271-277.

Teo, T. (2009) 'The impact of subjective norm and facilitating conditions on pre-service teachers' attitude toward computer use: a structural equation modeling of an extended technology acceptance model', Educational Computing Research, vol. 40, no. 1, pp. 186-210.

Thomas, M. (2011) Deconstructing Digital Natives, Routledge, New York.

Tsai, M., Chen, K. \& Chien, J. . . (2012) 'The factors impact of knowledge sharing intentions: the theory of reasoned action perspective', Qualitative and Quantitative, vol. 41, no. 1, pp. 1479-1491.

Venkatesh, V. \& Davis, F. D. (2000) 'A theoretical extension of the technology acceptance model: four longitudinal field studies', Management Science, vol. 46, no. 2, pp. 89-109. 


\section{T. Grigoryan}

Appendix A. Weekly journal.

Week_Unit Learning Outcomes

Reading and Writing

Speaking and Listening

Grammar and Vocabulary

\begin{tabular}{llll}
\hline iPad Group 1 & iPad Group 2 & Textbook Group 1 & Textbook Group 2 \\
\hline Day 1 & Day 1 & Day 1 & Day 1 \\
Day 2 & Day 2 & Day 2 & Day 2 \\
Day 3 & Day 3 & Day 3 & Day 3 \\
Day 4 & Day 4 & Day 4 & Day 4 \\
Day 5 & Day 5 & Day 5 & Day 5 \\
The teacher's & The teacher's & The teacher's & The teacher's \\
reflections & reflections & reflections & reflections \\
\hline
\end{tabular}

Appendix B. Reliability statistics.

Reliability Statistics

Cronbach's Alph a .808

$\mathrm{N}$ of Items

29

KMO and Bartlett's Test

Kaiser-Meyer-Olkin Measure of Sampling Adequacy.

Bardett's Test of Sphericity Approx.. Chi-Square

1712.739

df

406

Sig.

.000

Survey Analysis

\begin{tabular}{|c|c|c|c|c|c|c|c|}
\hline & \multicolumn{7}{|c|}{ Component } \\
\hline & 1 & 2 & 3 & 4 & 5 & 6 & 7 \\
\hline$\overline{\text { SLFREG01 }}$ & & & & & & & -.309 \\
\hline SLFREG02 & & & & & .620 & -.350 & \\
\hline Self-regulation 03 recoded & & & & & .733 & & \\
\hline SLFEF01 & .782 & & & & & & \\
\hline INTLRENV05 & .790 & & & & & & \\
\hline INTLRENV03 & .672 & & & .353 & & & \\
\hline INTLEENV01 & .722 & & & & & & \\
\hline SLFEF02 & -.733 & & & & & & \\
\hline SLFEF04 & .615 & .434 & & & & & \\
\hline INTLEENV06 & .486 & .463 & & & & & .402 \\
\hline EASEUS02 & .351 & & & & .510 & & \\
\hline USEFLNS03 & .440 & .418 & & .459 & & & .385 \\
\hline IPDTSK02 & & & & .691 & & & .320 \\
\hline SATISF01 & & .814 & & & & & \\
\hline
\end{tabular}


Survey Analysis (Continued)

\begin{tabular}{|c|c|c|c|c|c|c|c|}
\hline & \multicolumn{7}{|c|}{ Component } \\
\hline & 1 & 2 & 3 & 4 & 5 & 6 & 7 \\
\hline INTLRENV02 & & .841 & & & & & \\
\hline EASEUS03 & & & .564 & .586 & & & \\
\hline INTLEENV07 & & .538 & .496 & .448 & & & \\
\hline USEFLNS02 & -.441 & -.485 & -.337 & & & & \\
\hline IPDTSK01 & & .715 & .447 & .360 & & & \\
\hline MOTTV02 & & .393 & .683 & .324 & & & \\
\hline МОТМ в & & & .875 & & & & \\
\hline LRNEFFCT01 & & & .474 & .559 & & & \\
\hline LRKEFFCT02 & & .516 & .901 & & & & \\
\hline Ease of use recoded & & & & .406 & & .462 & \\
\hline iPad task 3 recoded & .430 & & .482 & & & .393 & \\
\hline Satisfactionj recoded & -.494 & -.669 & & & & & \\
\hline Satisfaction 2 recoded & & & & & & .820 & \\
\hline Motivation 1 recoded & & .304 & & .747 & & & \\
\hline Learning effectiveness recoded & & & & .774 & & & \\
\hline
\end{tabular}

Extraction Method: Principal Component Analysis.

Rotation Method: Varimax with Kaiser Normalisation.

${ }^{a}$ Rotation converged in 13 iterations.

Confirmatory factor analysis:

Factor name: Self-regulation

\begin{tabular}{lc}
\hline & Component Matrix $^{\mathrm{a}}$ \\
\cline { 2 - 2 } & Component \\
\hline SLFREG01 & 1 \\
SLFREG02 & .378 \\
Self-regulation 03 receded & .704 \\
\hline
\end{tabular}

Extraction Method: Principal Component Analysis.

a. 1 components extracted.

Factor name: Self-efficacy

\begin{tabular}{lc}
\hline & Component Matrix \\
& \\
\cline { 2 - 2 } & Component \\
\hline SLFEF01 & 1 \\
SLFEF04 & .828 \\
SIFEF02R & .843 \\
\hline
\end{tabular}

Extraction Method: Principal Component Analysis.

a. 1 components extracted. 


\section{T. Grigoryan}

Factor name: Interactive learning

Component Matrix ${ }^{\mathrm{a}}$

\begin{tabular}{lc}
\hline & Component \\
\cline { 2 - 2 } & \multicolumn{1}{c}{1} \\
\hline INTLRENV05 & .688 \\
INTLRENV03 & .677 \\
INTLRENV01 & .608 \\
INTLRENV06 & .812 \\
INTLRENV02 & .718 \\
INTLRENV07 & .702 \\
\hline
\end{tabular}

Extraction Method: Principal Component Analysis.

a. 1 components extracted.

Factor name: Ease of use

\begin{tabular}{lc}
\hline & Component Matrix \\
& \\
\cline { 2 - 2 } & Component \\
\hline EASEUS02 & 1 \\
EASEUS03 & .490 \\
Ease of use recoded & .821 \\
\hline
\end{tabular}

Extraction Method: Principal Component Anarysis.

a. 1 components extracted.

Factor name: iPad based tasks

\begin{tabular}{lc}
\hline & Coinmunalities \\
\hline & \\
\hline SATISF01 & Extraction \\
SATISF02 & .809 \\
SATISF03 & .055 \\
\hline
\end{tabular}

Extraction Method: Principal Component Analysis.

Factor name: Perceived usefulness

\begin{tabular}{lc}
\hline & Component Matrix $^{\mathrm{a}}$ \\
& \\
\cline { 2 - 2 } & Component \\
\hline IPDTSK02 & 1 \\
Ipad task 3 recoded & .759 \\
IPDTSK01 & .780 \\
\hline
\end{tabular}

Extraction Method: Principal Component Analysis.

a. 1 components extracted. 
Factor name: Perceived satisfaction

Component Matrix ${ }^{\mathrm{a}}$

\begin{tabular}{lc}
\hline & Component \\
\cline { 2 - 2 } & 1 \\
\hline USEFLNS01 & .630 \\
USEFLNS02 & .968 \\
Usefulness 3 Recoded & .968 \\
\hline
\end{tabular}

Extraction Method: Principal Component Analysis.

a. 1 components extracted.

Factor name: Motivation

Component Matrix"

\begin{tabular}{lc}
\hline & Component \\
\cline { 2 - 2 } & $\mathbf{1}$ \\
\hline MOTIV02 & 861 \\
MOTW03 & .857 \\
Motivation 1 recoded & .692 \\
Extraction Method: Principal Component Analysis. & \\
a. 1 components extracted. &
\end{tabular}

Factor name: Learning effectiveness

\begin{tabular}{lc}
\hline & Component Matrix 1 \\
\hline & \\
\cline { 2 - 3 } & Component \\
\hline LRNEFFCT0 1 & 1 \\
LRNEFFCT0 2 & .891 \\
Learning effecitveness recoded & .790 \\
\hline
\end{tabular}

Extraction Method: Principal Component Analysis.

a. 1 components extracted. 